\title{
First record of Pseudoryzomys simplex (Cricetidae, Sigmodontinae) in a flooded area of the Pantanal, Brazil
}

\author{
R. W. Wolfa, , R. V. Rossic, M. Aragona ${ }^{b, d}$ and D. M. Aguiar ${ }^{a, b *}$ \\ ${ }^{a}$ Laboratório de Virologia e Rickettsioses, Faculdade de Medicina Veterinária, Universidade Federal \\ do Mato Grosso - UFMT, Avenida Fernando Correa da Costa, 2367, CEP 78060-900, Cuiabá, MT, Brazil \\ 'Instituto Nacional de Ciência e Tecnologia em Áreas Úmidas - INAU, Rua Dois, 497, Boa Esperança, \\ CEP 78068-360, Cuiabá, MT, Brazil \\ 'Instituto de Biociências - IB, Universidade Federal de Mato Grosso - UFMT, Avenida Fernando Correa da Costa, 2367, \\ CEP 78060-900, Cuiabá, MT, Brazil \\ dInstituto de Engenharia, Universidade Federal de Mato Grosso - UFMT, Campus de Várzea Grande, \\ Avenida Fernando Correa da Costa, 2367, CEP 78060-900, Cuiabá, MT, Brazil \\ *e-mail: danmoura@ufmt.br
}

Received: June 9, 2015 - Accepted: August 5, 2015 - Distributed: November 30, 2016

(With 3 figures)

\begin{abstract}
Pseudoryzomys simplex is a small to medium sized terrestrial rodent confined to lowland open areas with strong seasonal rainfall throughout the Chaco, Cerrado and Caatinga. Despite its extensive range, the species is difficult to trap. In this report we provide the first record of P. simplex in the Pantanal, where three specimens were collected in a pasture of exotic grass. The specimens are morpometrically similar to the population from Paraguay (Chaco). In this sense, our report shows how interesting a taxonomic review of the species would be to better understand the real significance of the geographic variation herein observed.
\end{abstract}

Keywords: false Oryzomys, geographic distribution, Pantanal wetland.

\section{Primeiro registro de Pseudoryzomys simplex (Cricetidae, Sigmodontinae) em área alagada do Pantanal, Brasil}

\section{Resumo}

Pseudoryzomys simplex é um roedor terrestre de pequeno a médio porte que ocorre em áreas abertas de planícies com fortes precipitações sazonais ao longo dos Chaco, Cerrado e Caatinga. Apesar de sua extensa distribuição, a espécie é difícil de ser capturada. No presente estudo, fornecemos o primeiro registro de $P$. simplex no Pantanal, onde três espécimes foram coletados em uma pastagem de capim exótico. Os espécimes são morfometricamente semelhantes à da população do Paraguai (Chaco). Neste sentido, o nosso relatório mostra quão interessante seria uma revisão taxonômica das espécies para melhor compreender o significado real da variação geográfica aqui observada.

Palavras-chave: falso Oryzomys, distribuição geográfica, Pantanal.

The false Oryzomys Pseudoryzomys simplex (Winge, 1887 ) is a small to medium sized terrestrial sigmodontine rodent with head-and-body length between 94 and $140 \mathrm{~mm}$, tail length shorter or similar to the head-and-body length, varying from 105 to $140 \mathrm{~mm}$ (Voss and Myers, 1991), and weight between 45 and $55 \mathrm{~g}$ (Bonvicino et al., 2008). It exhibits long and soft pelage, which is grizzled-brownish or grayish dorsally and straw-colored or buffy ventrally, with gray-based hairs on the venter (Voss and Myers, 1991).

Available collecting localities are from northeastern Argentina, western Paraguay to eastern Bolivia, and from there eastward through Brazil and far in the northeastern portion of this latter country. This rodent is confined to lowland areas with strong seasonal rainfall, like grasslands and wetlands, found throughout the Chaco, Cerrado and Caatinga (Figure 1; Anderson, 1997; D'Elia et al., 2008; Pardiñas et al., 2004; Prado and Percequillo, 2013; Voss and Myers, 1991). Despite its extensive range, $P$. simplex was classified as rare (difficult to collect) and not abundant by Bonvicino et al. (2002). In fact, specimens of this rodent are more easily recorded through the analyses of Barn Owl (Tyto alba (Scopoli, 1769)) pellets (e.g. Pardiñas et al., 2004; Teta et al., 2009).

The Pantanal is the largest wetland in the world. The region is seasonally flooded and has a complex mosaic of habitats such as patches of forests, seasonally flooded grasslands and permanent or temporary lagoons (Nunes da Cunha and Junk, 2009). Although this region has the basic 


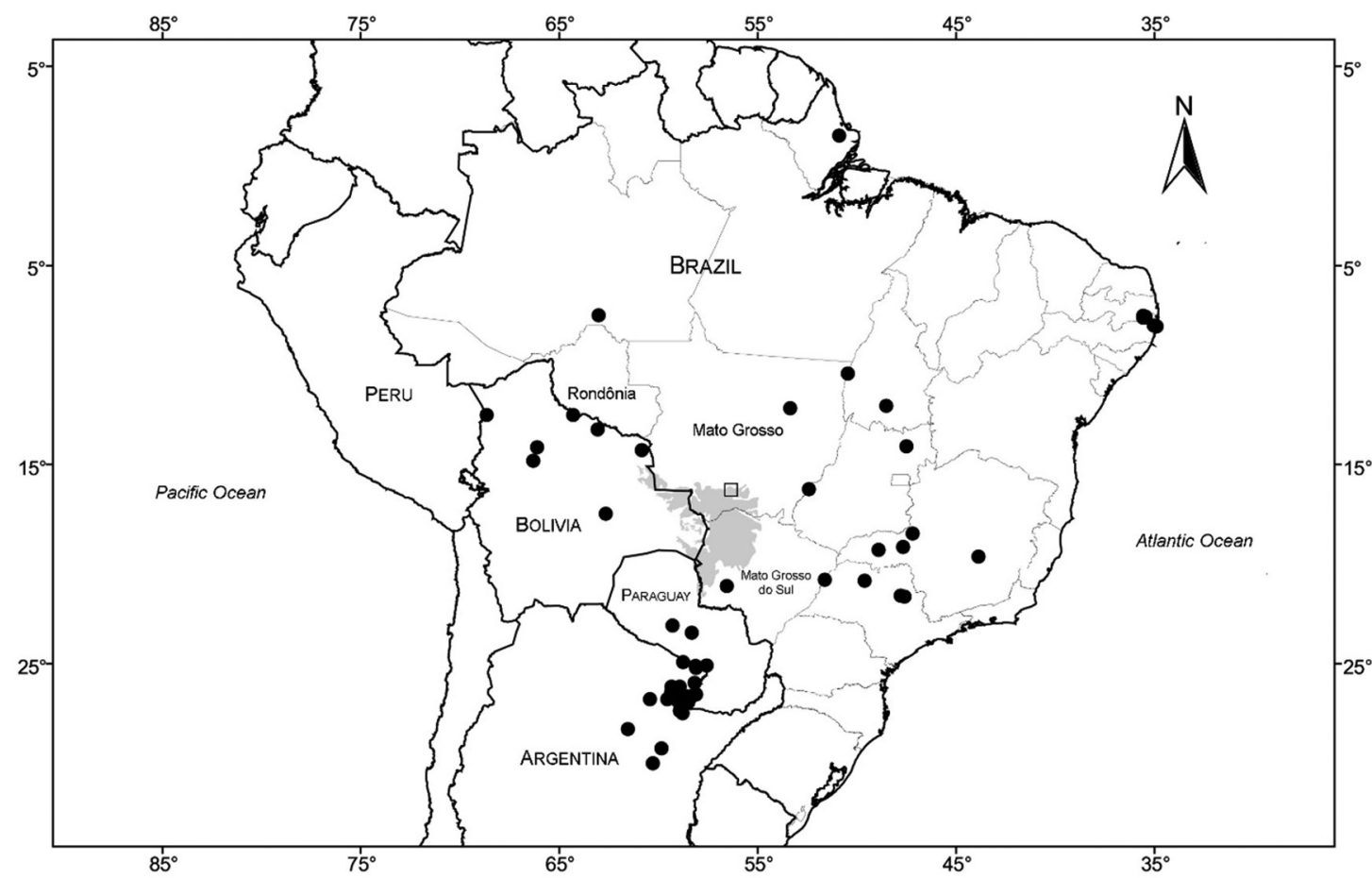

Figure 1. Collecting localities of Pseudoryzomys simplex (solid circles) based on Prado and Percequillo (2013) and the first collecting locality of the species (open square) in the Pantanal (gray area, based on Olson et al., 2001).

ecological features required by the false Oryzomys to exist, the species has never been recorded in it. Aragona (2008) provided a review of the small non-volant mammal species recorded in the Pantanal floodplain and the adjacent areas in the plateau, and none of the studies mentioned by her reports $P$. simplex in this region. As far as is known, the closest collecting localities of the species to the Pantanal limits are Parque Nacional de Noel Kempff Mercado, Santa Cruz, Bolivia (14 $16^{\prime}$ 'S, 60 $52^{\prime} \mathrm{W}$ ) and Gruta São Miguel, Mato Grosso do Sul, Brazil (21 ${ }^{\circ} 06^{\prime}$ S, 56 $34^{\circ}$ 'W) according to Prado and Percequillo (2013: figure 37). These localities are ca. $85 \mathrm{~km}$ and $70 \mathrm{~km}$ away from the Pantanal, respectively.

In this report we provide the first record of $P$. simplex for the Pantanal. Three specimens were collected in the county of Pirizal, municipality of Poconé, state of Mato Grosso, Brazil (16¹6'10.3S”, 56 201'12.1”W; Figure 1), two of which during the dry season on 04 October 2013, and one in wet season on 13 February 2014. The specimens were captured by wire cage traps set on the ground in a landscape that occasionally gets flooded during the wet season, covered with exotic pasture (Brachiaria humidicula (Rendle) Schweick.) and some sparse native shrubs and termite mounds (Figure 2). Traps were baited with a piece of pineapple and a paste made of peanut butter, corn flower, and sardine. An effort of 800 night-traps was employed in the study site.

The specimens collected by us are unequivocally identified as $P$. simplex by their long and soft grizzled-brownish

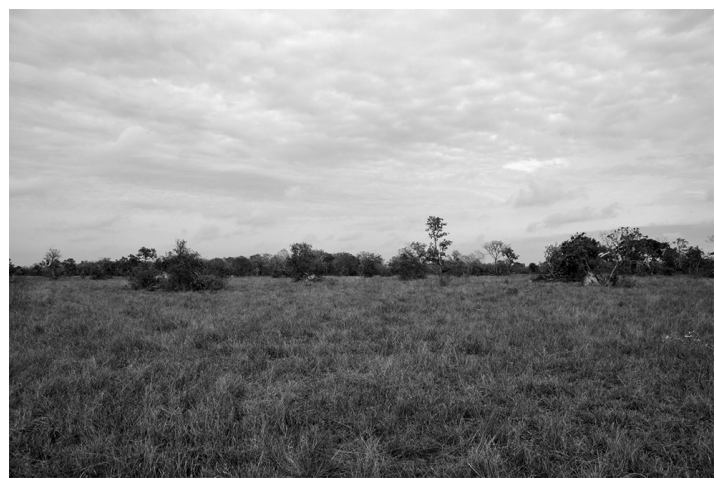

Figure 2. Landscape of exotic (Brachiaria humidicula) pasture and sparse native shrubs and termite mounds in the Pantanal where specimens of Pseudoryzomys simplex were collected. The place gets occasionally flooded in the wet season.

dorsal pelage; gray-based buffy ventral pelage; hind feet long and narrow with digits II-IV much longer than I and V; and bicolored tail about as long as head-and-body, with no terminal tuft. Craniodentally, they exhibit deep zygomatic notches; narrow interorbital region; supraorbital margins sharply edged; incisive foramina long, narrow, and parallel-sided; bony roof of mesopterygoid fossa perforated by large sphenopalatine vacuities; stapedial foramen minute or absent (Figure 3); and mesoloph small in M1 and M2 


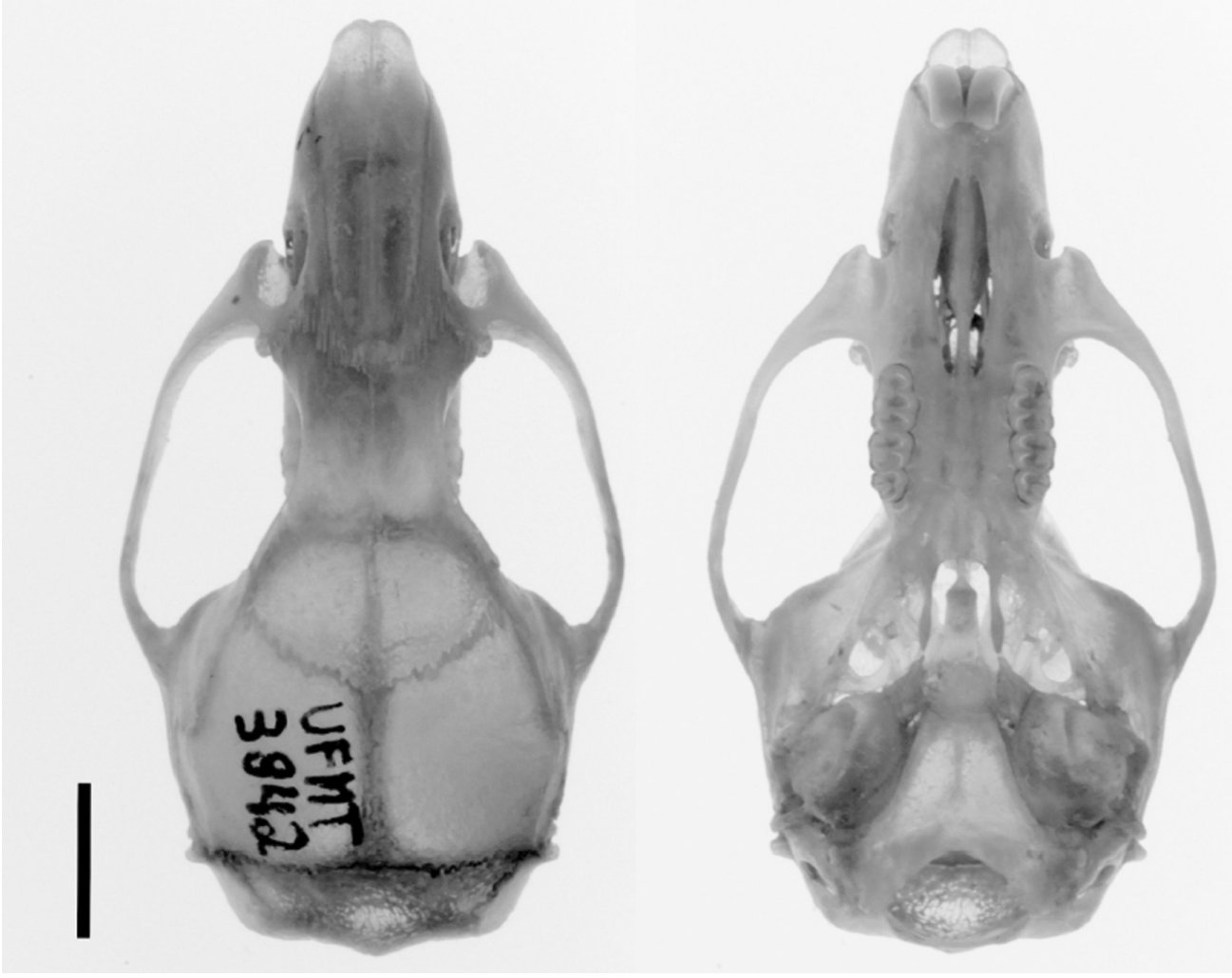

Figure 3. Dorsal and ventral views of the skull of Pseudoryzomys simplex collected in the Pantanal (UFMT 3842). Scale bar, $5 \mathrm{~mm}$.

and absent in M3, among other characteristics listed by Voss and Myers (1991) and Weksler and Percequillo (2011).

Measurements of our specimens (Table 1) average smaller than those from Bolivia and the state of Minas Gerais in Brazil reported by Voss and Myers (1991: tables 1-2), but conform to the population from Paraguay (Chaco) studied by the same authors, who highlighted this geographic variation in the size of the populations examined by them. Specimens from the Chaco, for example, average $26.05 \mathrm{~mm}$ in condylo-incisive length (CIL), $4.70 \mathrm{~mm}$ in length of molars (LM), and $4.35 \mathrm{~mm}$ in breadth of rostrum (BR), which are quite similar to the corresponding mean values $25.88 \mathrm{~mm}, 4.56 \mathrm{~mm}$, and $4.22 \mathrm{~mm}$ of our specimens (Table 1). In contrast, specimens from Bolivia average $28.70 \mathrm{~mm}$ in CIL, $4.85 \mathrm{~mm}$ in LM, and $4.70 \mathrm{~mm}$ in BR (Voss and Myers 1991).

Two previous studies were carried out in the same locality in order to sample small non-volant mammals. Aragona (2008) performed a huge capture effort (41,137 trap-nights) throughout two seasonal cycles of flooding, run-off and dry, but were focused in forest habitats. At the same time, Chupel (2008) performed 15,300 trap-nights of capture effort and sampled many types of seasonally flooded savanna parklands, using the RAPELD sampling system in a permanent grid proposed by Magnusson et al. (2005); for a description of the seasonally flooded open habitats in the Pantanal refer to Nunes da Cunha and Junk (2009). Together, these studies yielded six marsupial and nine
Table 1. Sex, measurements (in millimeters) and weight (in grams) of three adult specimens of Pseudoryzomys simplex collected in the Pantanal, precisely in the county of Pirizal, municipality of Poconé, state of Mato Grosso, Brazil.

\begin{tabular}{ccccc}
\hline & UFMT & UFMT & UFMT & \\
\cline { 2 - 4 } Sex & $\mathbf{3 8 4 2}$ & $\mathbf{3 8 4 3}$ & $\mathbf{3 8 4 4}$ & Mean \pm SD \\
\cline { 2 - 4 } Male & Female & Male & \\
\hline HBL & 120 & 109 & 110 & $113.0 \pm 6.1$ \\
LT & 115 & 111 & 121 & $115.7 \pm 5.0$ \\
Weight & 34 & 30 & 38 & $34.0 \pm 4.0$ \\
CIL & 26.33 & 25.81 & 25.49 & $25.88 \pm 0.42$ \\
LD & 7.69 & 7.48 & 7.03 & $7.4 \pm 0.34$ \\
LM & 4.38 & 4.63 & 4.66 & $4.56 \pm 0.15$ \\
BM1 & 1.39 & 1.52 & 1.47 & $1.46 \pm 0.07$ \\
LIF & 6.1 & 5.58 & 6.05 & $5.91 \pm 0.29$ \\
BR & 4.18 & 4.09 & 4.39 & $4.22 \pm 0.15$ \\
BPB & 2.67 & 2.52 & 2.03 & $2.41 \pm 0.33$ \\
BZP & 2.69 & 2.98 & 2.57 & $2.75 \pm 0.21$ \\
LIB & 4.31 & 4.01 & 4.06 & $4.13 \pm 0.16$ \\
BB & 12.15 & 12.26 & 11.93 & $12.11 \pm 0.17$ \\
DI & 1.61 & 1.6 & 1.36 & $1.52 \pm 0.14$ \\
LOF & 10.57 & 10.39 & 10.36 & $10.44 \pm 0.11$ \\
\hline Ext
\end{tabular}

External measurements are: HBL - Head-and-body length; LT - Length of tail; . Craniodental measurements are: CIL - Condylo-incisive length; LD - Length of diastema; LM - Length of molars; BM1 - Breadth of M1; LIF - Length of the incisive foramina; BR - Breadth of the rostrum; BPB - Breadth of the palatal bridge; $\mathrm{BZP}$ - Breadth of the zygomatic plate; $\mathrm{LIB}$ - east interorbital breadth; BB - Breadth of braincase; DI - Depth of the incisor; LOF - Length of the orbital fossa. For measurements explanation, refer to Voss and Myers (1991). 
rodent species, but none specimen of $P$. simplex was recorded (Chupel and Aragona, 2010).

As far as we know, this is the first time the species is collected in a landscape covered with exotic pasture. In this sense, our report of a population of P. simplex in the Brazilian Pantanal, which is morphometrically similar to a population in the Paraguayan Chaco, provides new geographical and ecological information on this poorly known sigmodontine rodent and also shows how interesting a taxonomic review of the species would be to better understand the real significance of the geographic variation herein observed.

\section{Acknowledgements}

This is a contribution of the Núcleo de Estudos Ecológicos do Pantanal (NEPA) from the Universidade Federal de Mato Grosso (UFMT). This study was supported by grants from the Centro de Pesquisas do Pantanal (CPP); Instituto Nacional de Ciências e Tecnologia em Áreas Úmidas, Ministério de Ciências e Tecnologia (INAU/MCT); and Coordenação de Aperfeiçoamento de Pessoal de Nível Superior (CAPES). RWW was supported by a Master fellowship from CAPES, MA was supported by a post-doctoral fellowship from PNPD/CAPES, and DMA was supported by a scientific productivity grant from Conselho Nacional de Desenvolvimento Científico e Tecnológico (CNPq). The small mammal specimens were collected with the authorization of Instituto Brasileiro do Meio Ambiente e Recursos Naturais Renováveis (IBAMA; license number 33068-3). We thank all the farmers in the Pantanal that authorized the activities of this research on their properties.

\section{References}

ANDERSON, S., 1997. Mammals of Bolivia, taxonomy and distribution. Bulletin of the American Museum of Natural History, no. 231, pp. 1-652.

ARAGONA, M., 2008. História natural, biologia reprodutiva, parâmetros populacionais e comunidades de pequenos mamiferos não voadores em três hábitats florestados do Pantanal de Poconé, MT. Brasília: Universidade de Brasília, 134 p. PhD Thesis in Animal Biology.

BONVICINO, C.R., LINDBERGH, S.M. and MAROJA, L.S., 2002. Small non-flying mammals from conserved and altered areas of Atlantic forest and Cerrado: comments on their potential use for monitoring environment. Brazilian Journal of Biology = Revista Brasileira de Biologia, vol. 62, no. 4B, pp. 1-12. http:// dx.doi.org/10.1590/S1519-69842002000500005. PMid:12659027.

BONVICINO, C.R., OLIVEIRA, J.A. and D'ANDREA, P.S., 2008. Guia dos Roedores do Brasil, com chaves para gêneros baseadas em caracteres externos. Rio de Janeiro: Centro PanAmericano de Febre Aftosa. 120 p.

CHUPEL, T.F. and ARAGONA, M., 2010. Pequenos mamíferos não voadores. In: I.M. FERNANDES, C.A. SIGNOR and J. PENHA. Biodiversidade no Pantanal de Poconé. Cuiabá: Centro de Pesquisa do Pantanal, pp. 155-168.

CHUPEL, T.F., 2008. Efeito da Cobertura vegetal e da topografia sobre a distribuição de marsupiais e roedores no Pantanal Norte, Mato Grosso. Cuiabá: Universidade Federal de Mato Grosso, 34 p. Masters Dissertation.

CUNHA, C.N. and JUNK, W.J., 2009. Landscape units of the Pantanal: structure, function, and human use. In: W.J. JUNK, C.J. SILVA, C.N. CUNHA and K.M. WANTZEN. The Pantanal: ecology, biodiversity and sustainable management of a large neotropical seasonal wetland. Sofia: Pensoft Publishers, pp. 301-326.

D'ELÍA, G., MORA, I., MYERS, P. and OWEN, R.D., 2008. New and noteworthy records of Rodentia (Erethizontidae, Sciuridae, and Cricetidae) from Paraguay. Zootaxa, vol. 1784, pp. 39-57.

MAGNUSSON, W.E., LIM, A.P., LUIZÃO, R., LUIZÃO, F., COSTA, F.R.C., CASTILHO, C.V. and KINUPP, V.F., 2005. RAPELD: uma modificação do método de Gentry para o levantamento da biodiversidade em áreas. Biota Neotropica, vol. 5, no. 2, pp. 1-6.

OLSON, D.M., DINERSTEIN, E., WIKRAMANAYAKE, E.D., BURGESS, N.D., POWELL, G.V.N., UNDERWOOD, E.C., D'AMICO, J.A., ITOUA, I., STRAND, H.E., MORRISON, J.C., LOUCKS, C.J., ALLNUTT, T.F., RICKETTS, T.H., KURA, Y., LAMOREUX, J.F., WETTENGEL, W.W., HEDAO, P. and KASSEM, K.R., 2001. Terrestrial ecoregions of the world: a new map of life on Earth. Bioscience, vol. 51, no. 11, pp. 933-938. http://dx.doi.org/10.1641/0006-3568(2001)051[0933:TEOTW A]2.0.CO;2.

PARDIÑAS, U.F.J., CIRIGNOLI, S. and GALLIARI, C.A., 2004. Distribution of Pseudoryzomys simplex (Rodentia: Cricetidae) in Argentina. Mastozoología Neotropical, vol. 11, no. 1, pp. 105-108.

PRADO, J.R. and PERCEQUILLO, A.R., 2013. Geographic distribution of the genera of the tribe Oryzomyini (Rodentia: Cricetidae: Sigmodontinae) in South America: patterns of distribution and diversity. Arquivos de Zoologia, vol. 44, no. 1, pp. 1-120. http://dx.doi.org/10.11606/issn.2176-7793.v44i1p1-120.

TETA, P., PEREIRA, J.A., MUSCHETTO, E. and FRACASSI, N., 2009. Mammalia, Didelphimorphia, Chiroptera, and Rodentia, Parque Nacional Chaco and Capitán Solari, province of Chaco, Argentina. Check List, vol. 5, no. 1, pp. 144-150.

VOSS, R.S. and MYERS, P., 1991. Pseudoryzomys simplex (Rodentia, Muridae) and the significance of Lund's collections from the caves of Lagoa Santa, Brazil. Bulletin of the American Museum of Natural History, vol. 206, pp. 414-432.

WEKSLER, M. and PERCEQUILLO, A.R., 2011. Key to the genera of Tribe Oryzomyini (Rodentia: Cricetidae: Sigmodontinae). Mastozoología Neotropical, vol. 18, no. 2, pp. 281-291. 